\title{
Amino acids as selective sulfonamide acylating agents ${ }^{\text {光 }}$
}

\author{
Paula Gomes, ${ }^{\text {a,* }}$ José R. B. Gomes, ${ }^{\text {a }}$ Manuela Rodrigues ${ }^{\mathrm{a}}$ and Rui Moreira ${ }^{\mathrm{b}}$ \\ ${ }^{a}$ Centro de Investigação em Química da Universidade do Porto, Departamento de Química da Faculdade de Ciências do Porto, \\ Rua do Campo Alegre 687, P-4169-007 Porto, Portugal \\ ${ }^{\mathrm{b}}$ Centro de Estudos de Ciências Farmacêuticas, Faculdade de Farmácia da Universidade de Lisboa, Av. Forças Armadas, \\ P-1649-019 Lisboa, Portugal
}

Received 16 June 2003; accepted 30 July 2003

\begin{abstract}
Acylation of antimalarial and bacteriostatic sulfonamides with $N$-protected amino acids and peptides was carried out using standard peptide coupling methods. These acylation reactions are regioselective for the $N^{4}$ nitrogen atom of diazine-containing sulfonamides. In contrast, only $N^{1}$ coupling was found for sulfisoxazole, an isoxazole-based sulfonamide. Computational studies suggest that a combination of geometrical, thermodynamic and electronic factors are responsible for the different reactivities reported.

(C) 2003 Elsevier Ltd. All rights reserved.
\end{abstract}

\section{Introduction}

Prodrug synthesis is a widely used strategy to improve the delivery of drugs to their site of therapeutic action. ${ }^{1}$ The most important application of the prodrug strategy is the increase of the oral bioavailability of poorly absorbed drugs. $^{2}$ Prodrugs can release the parent drug either by chemical or enzymatic activation. Although enzymatic activation is preferred when the objective is site-specific drug delivery (e.g. by designing a prodrug that is selectively activated by a specific enzyme ${ }^{3}$ ), chemical prodrug

\footnotetext{
Supplementary data associated with this article can be found at doi: 10 . 1016/S0040-4020(03)01206-7
}

Keywords: acylation; density functional theory; prodrugs; regioselectivity; sulfonamides.

Abbreviations: $\mathrm{Ac}_{2} \mathrm{O}$, acetic anhydride; $\mathrm{AcOH}$, acetic acid; $\mathrm{ACN}$, acetonitrile; Ala, alanine residue; anal. calcd, analysis calculated; app. decn., apparent decomposition at; B3LYP, Becke's three-parameter hybrid functional using the LYP correlation functional; Boc, tertbutyloxycarbonyl (protecting group); bs, broad singlet; $\mathrm{CDCl}_{3}$, deuterated chloroform; $\mathrm{d}$, doublet; $\delta$, chemical shift (in ppm); DCCI, $N, N^{\prime}$-dicyclohexylcarbodiimide DCM, dichloromethane; DCU, $N, N^{\prime}$-dicyclohexylurea; dd, double doublet; DFT, density functional theory; DHB, 2,5-dihydroxybenzoic acid; DIEA, diisopropylethylamine; DMAP, $N, N$-dimethyl-4-pyridinamine (4-dimethylaminopyridine); DMSO- $\mathrm{d}_{6}$, hexadeuterated dimethyl sulfoxide; Gly, glycine residue; HBTU, 2-(1H-benzotriazole-1-yl)-1,1,3,3-tetramethyluronium hexafluorophosphate; $\mathrm{HOBt}, \mathrm{N}$-hydroxybenzotriazole; LPLC, low pressure liquid chromatography; LYP, Lee, Yang and Parr correlation functional; $\mathrm{m}$, multiplet; $\mathrm{mp}$, melting point; MALDI-TOF, matrix-assisted laser desorption ionisation-time-of-flight; MS, mass spectrometry; NBO, natural bond orbital; NMR, nuclear magnetic resonance; Phe, phenylalanine residue; ppm, parts per million (NMR chemical shift unit); q, quartet; r.p.m., revolutions per minute; s, singlet; t, triplet; THF, tetrahydrofuran; TMS, tetramethylsilane; Z, benzyloxycarbonyl (protecting group).

* Corresponding author. Tel.: +351-226082863; fax: +351-226082822; e-mail:pgomes@fc.up.pt activation has the advantage of not being affected by biological variability. ${ }^{4} \mathrm{~A}$ major requirement for any prodrug is the quantitative formation of the parent drug. This objective can be easily achieved by taking the advantage of facile intramolecular cyclization reactions. ${ }^{5-7}$

Although sulfonamides are best known as bacteriostatic ${ }^{8}$ and antimalarial agents, ${ }^{9}$ there is now a range of drugs, possessing very different pharmacological activities, in which the sulfonamide group is present. ${ }^{10}$ Several of these drugs suffer from bioavailability problems or adverse secondary effects. ${ }^{11-13}$ The prodrug strategy has been widely used for solving biopharmaceutical problems of this nature. Although several prodrugs have been specifically developed for sulfonamide agents, only few have displayed adequate chemical and/or enzymatic activation rates. ${ }^{14-17}$ The main interest of our research team concerns the development of intramolecular cyclization-activated prodrugs for antimalarial sulfonamides as potential long-acting agents useful against chloroquine-resistant Plasmodium falciparum strains. Our target molecules involve drug modification with dipeptide carriers that can release the parent drug through a non-enzymatic mechanism, i.e. intramolecular cyclization to a 2,5-diketopiperazine. ${ }^{18,19}$ The dipeptide carrier can be linked to the sulfonamide either via the 4-anilino group $\left(N^{4}\right.$ nitrogen atom), i.e. 1, or via the sulfonamido group $\left(N^{1}\right.$ nitrogen atom), i.e. 2 (Fig. 1). The corresponding prodrugs are expected to undergo cyclization at significantly different rates due to the large differences in the leaving group abilities of the anilino and sulfonamido groups. We set out to use classical peptide synthetic reactions to prepare compounds $\mathbf{1}$ and $\mathbf{2}$. However, as described in the present paper, we observed that sulfonamides are invariably acylated at $N^{4}$ in a regioselective fashion. This contrasts 
<smiles>[R]C(N)C(=O)N[C@@H](CC)C(=O)Nc1ccc(S(=O)(=O)N[Al])cc1</smiles><smiles>[R]C(N)C(=O)N[C@@H](C)[C@H](C)C(=O)N([Al])S(=O)(=O)c1ccc(N)cc1</smiles><smiles>Nc1ccc(S(=O)(=O)NBr)cc1</smiles>
3<smiles>[R]C1NC(=O)C([R])NC1=O</smiles>
4<smiles>COc1cnnc(C)c1</smiles>

Figure 1. Dipeptide carriers in sulfonamide prodrugs: drug release by intramolecular cyclization with 2,5-diketopiperazine formation.

sharply with reaction with other acylating agents, such as acetic anhydride, which can lead to $N^{1}$ and $N^{4}$ acylation. To obtain more information about the coupling reactions of sulfonamides with amino acids and dipeptides, we took advantage of recent advances in computational chemistry. Density Functional Theory, DFT, has been applied successfully in several fields of knowledge due to its ability to predict geometrical and energetic values, which compare excellently with experimental data. In the present work, DFT calculations, carried out at the B3LYP/6-311+G**// B3LYP/6-31G* level of theory, on the possible acylation products from reaction of the four sulfonamides with amino acid glycine have provided a possible explanation for our experimental findings. The degree of $N^{1}$ or $N^{4}$ acylation is shown to be governed by relative energetics of the reaction products.

\section{Results and discussion}

\subsection{Acylation of sulfonamides with protected amino acids and dipeptides}

All syntheses were based in standard peptide coupling methods ${ }^{20}$ and involved $N^{\alpha}$-protected amino acid coupling to the sulfa drug, using DCCI, ${ }^{21} \mathrm{HBTU} / \mathrm{DIEA},{ }^{22,23} \mathrm{Ph}_{3} \mathrm{P} /$ $\mathrm{CCl}_{4}{ }^{24}$ in combination with the auxiliary nucleophiles HOBt, ${ }^{25,26}$ DMAP. ${ }^{27}$

Since we were equally interested in both $N^{1}$ and $N^{4}$ acylated sulfonamides, we devised synthetic strategies in order to favor the formation of either one or the other monoacyl derivative. Thus, we assayed different synthetic routes using sulfamethazine and $N^{\alpha}$-protected glycine as the acylating agent. Regardless of the strategy employed, we consistently obtained only one monoacylation product (Table 1, entries A, B, S and T), which was found to be the $N^{4}$-acyl derivative by NMR spectroscopy (absence of the sulfamethazine $\mathrm{Ar}-\mathrm{NH}_{2}$ peak, replaced by a new $\mathrm{NH}$ signal at ca. $10 \mathrm{ppm}$ ). The lack of reactivity of $N^{4}$. acetylsulfamethazine further confirmed that coupling at $N^{4}$ is the favored acylation pathway (Table 1, entries $\mathrm{U}$ and $\mathrm{V})$.

Regioselective acylation at the $N^{4}$ atom was consistently observed for other $N^{\alpha}$-protected amino acids and dipeptides (Table 1, entries $\mathrm{C}-\mathrm{G}$ ), as well as for other two sulfonamides, namely, sulfadimethoxine and sulfamethoxypyridazine (Table 1, entries $\mathrm{H}-\mathrm{O}$ ). These share with sulfamethazine the presence of a diazine ring linked to the sulfonamido group (Fig. 1).

Despite the results described in the previous section, when we stepped forward to sulfisoxazole, a sulfonamide that contains an isoxazole instead of a diazine ring (Fig. 1), we found that this drug was almost non-reactive in terms of acylation with amino acids and dipeptides. Irrespective of synthetic method employed, we obtained high recovery levels of the parent drug ( $\geq 70 \%$ of initial amount) together with complex and intractable reaction mixtures (Table 1, entries $\mathrm{P}$ and $\mathrm{Q}$ ). The complexity of crude mixtures, together with the low extension of sulfisoxazole conversion, 
Table 1. Amino acid and dipeptide coupling reactions

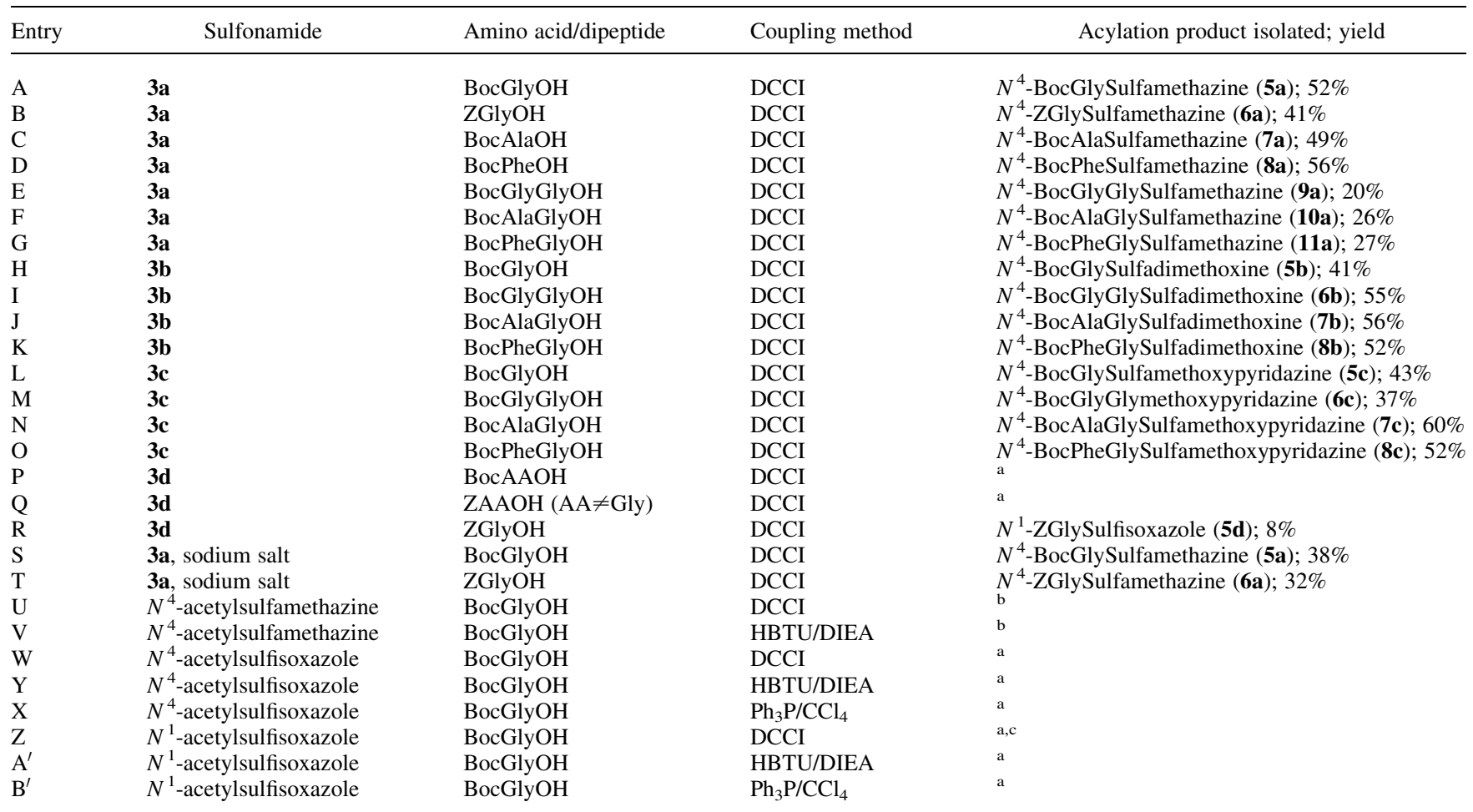

a Intractable mixture-no products isolated; high recovery levels of starting materials.

b No products; full recovery of starting materials.

${ }^{\mathrm{c}} N^{1}$-deacetylation occurred when the DMAP catalyst was used together with DCCI.

disabled us to isolate the putative acylsulfisoxazoles, except for one single case in which a few milligrams of one product were isolated (Table 1, entry R) and characterized by NMR spectroscopy as corresponding to the $N^{1}$-acyl derivative (no signals were seen above $8 \mathrm{ppm}$ and the sulfonamide $\mathrm{Ar}-\mathrm{NH}_{2}$ protons were observed at $6.54 \mathrm{ppm}$ ).

To confirm that sulfisoxazole could be acylated at either the $N^{1}$ and the $N^{4}$ atoms by other acylating agents, we prepared $N^{1}$-acetyl, $N^{4}$-acetyl and $N^{1}, N^{4}$-diacetylsulfisoxazole with very good yields (data not shown), based on methods described in the literature. We then tried to force acylation of the $N^{1}$ - and $N^{4}$-monoacetylsulfisoxazoles prepared with $N^{\alpha}$-protected glycine, by three different coupling methods. Again, all these assays were unsuccessful and no products could be isolated (Table 1, entries $\left.\mathrm{W}-\mathrm{B}^{\prime}\right)$.

The results presented in Table 1 suggest that the site of acylation with amino acids and dipeptides is independent of either coupling method or solvent employed, and these two factors affected only the synthesis yield. Thus, we decided to search for a rational explanation for these experimental findings, through computational chemistry calculations on the possible acylation products of the four sulfonamides when reacted with glycine. In this context, and as described in the following sections, we started with molecular geometry optimization for both reactants and products, and then we stepped forward to the theoretical analysis of the reaction energetics. The occupancy of the lone-pair in sulfonamide $N^{1}$ and $N^{4}$ atoms, based on Natural Bond Orbital (NBO) analysis, was also calculated.

\subsection{Molecular structures}

Relevant geometrical parameters of the reactants and their $\mathrm{N}$-acyl derivatives were obtained at the B3LYP/6-31G(d) level of theory. These optimized structures were reached by performing a full-optimization without symmetry constraints. Analyzing the bond distances of atoms directly bonded to sulfur it is shown that there are not appreciable differences in the sulfur-oxygen bond lengths. The values obtained negligibly differ from those described in a previous work concerning the $\mathrm{HS}\left(\mathrm{O}_{2}\right) \mathrm{NH}_{2}$ sulfonamide, $1.462 \AA .{ }^{28}$ However, when we turn our attention to what happens with the $\mathrm{S}-\mathrm{N}$ bonds in each species considered in the present work, it is clear that this bond is rather elongated, by a maximum of $0.06 \AA$, when compared with the computed $\mathrm{S}-\mathrm{N}$ bond in $\mathrm{HS}\left(\mathrm{O}_{2}\right) \mathrm{NH}_{2} \cdot{ }^{28}$ Bharatam et al. have computed for the most stable $\mathrm{HS}\left(\mathrm{O}_{2}\right) \mathrm{NH}_{2}$ isomer a $\mathrm{S}-\mathrm{N}$ distance of $1.667 \AA$ or $1.682 \AA$ by employing the MP2/6-31+G* and $\mathrm{B} 3 \mathrm{LYP} / 6-31+\mathrm{G}^{*}$ approaches, respectively. These differences may be attributed to stereoelectronic effects due to the presence of two aromatic rings, which comes into agreement with previous findings of Bharatam et al. describing the increase of the $\mathrm{S}-\mathrm{N}$ bond length with an increase in the electron donating nature of $\mathrm{X}$ in $\mathrm{XS}(\mathrm{O})_{2} \mathrm{NH}_{2}{ }^{28}$ In fact, using $\mathrm{B} 3 \mathrm{LYP} / 6-31+\mathrm{G}^{*}$, we have calculated a $\mathrm{S}-\mathrm{N}$ bond distance of $1.692 \AA$ for the $\mathrm{PhS}\left(\mathrm{O}_{2}\right) \mathrm{NH}_{2}$ species, confirming the $\mathrm{S}-\mathrm{N}$ elongation effect of an aromatic ring bonded to the sulfur atom. This value for $\mathrm{PhS}\left(\mathrm{O}_{2}\right) \mathrm{NH}_{2}$ is now only $0.2 \AA$ shorter than the computed $\mathrm{S}-\mathrm{N}$ lengths for compounds $\mathbf{3 a}-\mathbf{3 c}$, but still $0.4 \AA$ shorter than for compound 3d (Fig. 2). In the latter compound, the larger $\mathrm{S}-\mathrm{N}$ bond length is due to a higher distortion of the 


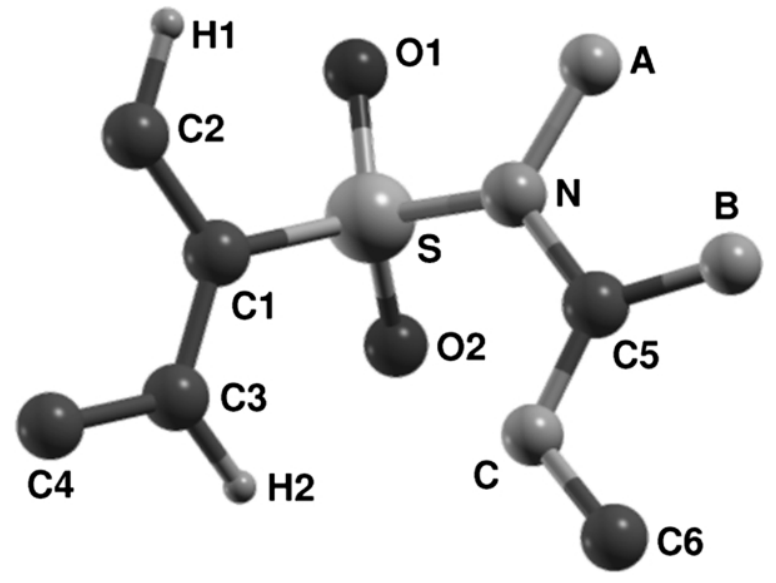

Figure 2. Atom numbering scheme used to define bond lengths and angles reported as Supplementary Data. For simplicity, only part of the molecular structure is shown; (A) is hydrogen or carbon, (B) is nitrogen or oxygen and (C) is nitrogen or carbon.

sulfonamide by a stronger pyramidalization at the $\mathrm{N}$ atom (the $\mathrm{S}-\mathrm{N}-\mathrm{C} 5$ angle decreases by $5^{\circ}$ ). The larger $\mathrm{S}-\mathrm{N}$ and $\mathrm{A}-\mathrm{B}$ distances and the higher dihedral $\mathrm{A}-\mathrm{N}-\mathrm{C} 5-\mathrm{B}$ angle observed for compound $\mathbf{3 d}$ contribute to a greater exposure of the $-\mathrm{SO}_{2} \mathrm{NH}-$ group, eventually favoring the approach of the acylation agent.

\subsection{Energetics of acylation reactions}

The enthalpies of the reactions of sulfonamides $\mathbf{3 a}-\mathbf{d}$ with glycine, considering acylation at either the $N^{1}$ or the $N^{4}$ position, were calculated using the $\mathrm{H}_{298.15 \mathrm{~K}}$ values reported as Supplementary Data, and the final results are given in Table 2. From the results herewith reported it is noticed that the reaction is always endothermic. The calculated enthalpies of reaction fall in the $26-76 \mathrm{~kJ} \mathrm{~mol}^{-1}$ interval and it is interesting to note that acylation at $N^{4}$ is preferred. The largest difference in enthalpies of reaction between acylation at $N^{4}$ and $N^{1}$ is found for $\mathbf{3 a}$ while the smallest energetic difference was calculated for 3d. Since the reactant and product geometries are similar in reactions a to $\mathrm{h}$, please see Table 2 and geometric parameters given as Supplementary Data, we may argue that the influence of the solvent will be almost the same for these species. Therefore, the enthalpic differences computed in the gas-phase may be used to extract information about the reaction profiles in solution. Thus, it is concluded that reaction at $N^{4}$ position is clearly preferred for 3a-c while for 3d, with an enthalpy difference of only $2.8 \mathrm{~kJ} \mathrm{~mol}^{-1}$, acylation at the sulfonamido or the anilino group should occur with equal probability. This could explain

Table 2. Enthalpies of reaction between sulfanilamides $\mathbf{3 a}-\mathbf{d}$ and glycine at both positions $N^{1}$ or $N^{4}$ computed at the B3LYP/6-311+G**//B3LYP/ 6-31G* level of theory

\begin{tabular}{|c|c|}
\hline Reaction & $\Delta H_{298.15 \mathrm{~K}},\left(\mathrm{~kJ} \mathrm{~mol}^{-1}\right)$ \\
\hline (a) $\mathbf{3 a}+$ glycine $\longrightarrow \mathbf{3} \mathbf{a} \mathbf{N}^{\mathbf{1}}+\mathrm{H}_{2} \mathrm{O}$ & 76.1 \\
\hline (b) $\mathbf{3 a}+$ glycine $\rightarrow \mathbf{3 a N}^{\mathbf{4}}+\mathrm{H}_{2} \mathrm{O}$ & 26.0 \\
\hline (c) $\mathbf{3 b}+$ glycine $\rightarrow \mathbf{3 b \mathbf { N } ^ { 1 }}+\mathrm{H}_{2} \mathrm{O}$ & 68.5 \\
\hline (d) $\mathbf{3 b}+$ glycine $\rightarrow \mathbf{3 b N} \mathbf{N}^{4}+\mathrm{H}_{2} \mathrm{O}$ & 28.8 \\
\hline (e) $\mathbf{3 c}+$ glycine $\rightarrow \mathbf{3} \mathbf{c} \mathbf{N}^{\mathbf{1}}+\mathrm{H}_{2} \mathrm{O}$ & 50.3 \\
\hline (f) $\mathbf{3 c}+$ glycine $\rightarrow \mathbf{3} \mathbf{c N}^{\mathbf{4}}+\mathrm{H}_{2} \mathrm{O}$ & 37.5 \\
\hline (g) $\mathbf{3 d}+$ glycine $\rightarrow \mathbf{3} \mathbf{d} \mathbf{N}^{\mathbf{1}}+\mathrm{H}_{2} \mathrm{O}$ & 34.4 \\
\hline (h) $\mathbf{3 d}+$ glycine $\rightarrow \mathbf{3} \mathbf{d N}^{\mathbf{4}}+\mathrm{H}_{2} \mathrm{O}$ & 31.6 \\
\hline
\end{tabular}

Table 3. Lone pair occupancy in sulfonamide $N^{1}$ and $N^{4}$ atoms, based in a Natural Bond Orbital analysis

\begin{tabular}{llll}
\hline Compound & \multicolumn{2}{c}{$N^{1}$} & \multirow{2}{*}{$N^{4}$ (neutral) } \\
\cline { 2 - 3 } & Neutral & Anionic & \\
\hline 3a & 1.787 & 1.554 & 1.824 \\
3b & 1.796 & 1.570 & 1.816 \\
3c & 1.836 & 1.617 & 1.816 \\
3d & 1.861 & 1.665 & 1.815 \\
\hline
\end{tabular}

both the experimental identification of an $N^{1}$-acylsulfizoxazole and the complexity of crude mixtures in sulfisoxazole reactions, possibly due to parallel formation of $N^{1}$-acyl, $N^{4}$ acyl and even $N^{1}, N^{4}$-di-acylsulfisoxazoles.

\subsection{Lone-pair occupancy in $N^{1}$ and $N^{4}$ as determined by NBO analysis}

Occupancies of the sulfonamide $N^{1}$ or $N^{4}$ lone pairs were extracted from NBO analysis, ${ }^{29}$ and are shown in Table 3. From this analysis, the following should be pointed out. First, the occupancy of the lone pair in $N^{1}$ atoms is clearly higher for sulfisoxazole, both in neutral and anionic forms. Second, the $N^{1}$-anionic form presents a significantly lower lone-pair occupancy when compared with the neutral form. Third, the occupancies of the $N^{4}$ lone pairs are similar for the four sulfonamides.

These results are consistent with the fact that only the coupling reaction of sulfisoxazole with a protected amino acid led to the isolation of an $N^{1}$-acyl derivative. Moreover, the results also suggest that using sulfonamide $N^{1}$-conjugated bases will not increase the availability of the $N^{1}$ lone pair to react with acylating agents. Indeed, we were not able to prepare any $N^{1}$-acyl derivatives using sulfonamide sodium salts as starting reagents.

\section{Conclusions}

Taken together, our results are clear evidence that amino acids, unlike other acyl reagents (e.g. $\mathrm{Ac}_{2} \mathrm{O}$ ), are selective sulfonamide acylating agents. This selectivity is not influenced by the coupling method employed and is reflected in the regioselective attack of amino acids and dipeptides to the anilino group $\left(N^{4}\right)$ of diazine-containing sulfas, as well as in the completely different behavior towards different types (diazine vs isoxazole) of sulfonamides. From what is above exposed, our experimental findings seem to be explainable if we consider a combination of geometrical, thermodynamic and electronic factors. The results herein reported suggest that coupling amino acids and dipeptides to the sulfonamide $N^{1}$ atom is not feasible using standard peptide coupling chemistry and thus new procedures should be devised.

\section{Materials and methods}

\subsection{General details}

$N^{\alpha}$-Protected amino acids and dipeptides were purchased 
from NovaBiochem (Switzerland) and Bachem (Switzerland), respectively. Solvents were all of p.a. quality and bought to Merck (Germany). Thin layer chromatography glass plates, covered with silica $60 \mathrm{~F}_{254}(0.25 \mathrm{~mm})$, and silica-gel 60 (70-230 mesh ASTM) for preparative column chromatography were also from Merck. When required, solvents were previously dried with pre-activated molecular sieves ( $4 \AA$ ), equally bought to Merck. Other chemicals were from Sigma-Aldrich.

NMR spectra of compounds solubilized in hexadeuterated dimethyl sulfoxide (DMSO- $\mathrm{d}_{6}$ ), adding tetramethylsilane (TMS) as internal reference, were acquired on a Brücker AC200 spectrometer. Mass spectrometry (MS) was performed by the matrix-assisted laser desorption ionizationtime-of-flight (MALDI-TOF) technique on a Finnigan MAT Lasermat 2000, using 2,5-dihydroxibenzoic acid (DHB) as adjuvant matrix.

Synthetic details are described only for reactions that led to novel sulfonamide derivatives in higher yields. Generally, $\mathrm{N}$-acylsulfonamides were prepared by condensation with amino acids or dipeptides, using classical peptide chemistry. ${ }^{20}$ Thus, dicyclohexylcarbodiimide-DCCI ${ }^{21}$ coupling, either in the presence or absence of the $N, N$-dimethyl-4-pyridinamine (DMAP) acylation catalyst, ${ }^{27}$ was successfully employed. Whenever the DCCI coupling did not occur as expected, alternative strategies such as the $\mathrm{Ph}_{3} \mathrm{P} / \mathrm{CCl}_{4},{ }^{24}$ the HBTU/DIEA ${ }^{22,23}$ or the HBTU/HOBt/ DIEA $^{26}$ methods were also tested. $N^{\alpha}$-protected amino acids or dipeptides were employed in the condensation steps.

$N^{4}$-Acetylsulfamethazine as well as $N^{1}-, N^{1}, N^{4}$ - and $N^{4}$ acetylsulfisoxazoles had been previously synthesized, ${ }^{30-34}$ thus reported methods were employed for their preparation; target compounds were successfully obtained in high yields, and possessed the correct physical and chemical properties (melting points, ${ }^{1} \mathrm{H}$ and ${ }^{13} \mathrm{C}$ NMR chemical shifts, molecular weights and elemental analyses-data not shown).

\subsection{Sulfonamide acylation with $N^{\alpha}$-protected amino acids or dipeptides}

4.2.1. $\quad N^{4}$-BocGlySulfamethazine (5a). To a stirred solution of $N^{\alpha}$-BocGlycine $(2.0 \mathrm{mmol})$ in dry tetrahydrofuran (THF) was carefully added DCCI $(2.2 \mathrm{mmol})$ at $0^{\circ} \mathrm{C}$, followed by DMAP $(0.2 \mathrm{mmol})$ and sulfamethazine $(2.0 \mathrm{mmol})$; the mixture was stirred at $0^{\circ} \mathrm{C}$ for $1 \mathrm{~h}$ and then at room temperature for one day; the insoluble dicyclohexylurea (DCU) was removed by suction filtration and, after THF evaporation, warm acetone was added to the oily residue; the solution was allowed to stand at $4^{\circ} \mathrm{C}$ overnight and additional DCU was precipitated and removed by filtration; the filtrate was vacuum dried and the viscous oil obtained was then eluted on a silica-gel column, using dichloromethane (DCM)/Acetone 5:1 (v/v); fractions containing pure product were pooled and evaporated to dryness; the resulting white solid (52\%) was recrystallized from chloroform $\left(\mathrm{mp} 182-184^{\circ} \mathrm{C}\right) . \quad \delta_{\mathrm{H}}$ $\left(\mathrm{DMSO}_{\mathrm{d}}\right), 11.62$ (bs, 1H), 10.31 (s, 1H), 7.94 (d, $J=8.7 \mathrm{~Hz}, 2 \mathrm{H}), 7.73(\mathrm{~d}, J=8.7 \mathrm{~Hz}, 2 \mathrm{H}), 7.11(\mathrm{t}, J=6.0 \mathrm{~Hz}$,
$1 \mathrm{H}), 6.75(\mathrm{~s}, 1 \mathrm{H}), 3.74(\mathrm{~d}, J=6.0 \mathrm{~Hz}, 2 \mathrm{H}), 2.25$ (s, 6H), 1.39 $(\mathrm{s}, 9 \mathrm{H}) ; \delta_{\mathrm{C}}\left(\mathrm{DMSO}_{\mathrm{d}}\right), 168.8,168.4,156.1,155.9,134.3$, 129.3, 117.9, 113.4, 78.0, 43.8, 28.1, 22.8. Anal. calcd for $\mathrm{C}_{19} \mathrm{H}_{25} \mathrm{~N}_{5} \mathrm{O}_{5} \mathrm{~S}$ (435.5): C, 52.40; H, 5.79; N, 16.08; S, $7.36 \%$. Found: C, 52.16; H, 5.90; N, 15.67; S, 7.18\%.

4.2.2. $N^{4}$-ZGlySulfamethazine (6a). The synthesis procedure was exactly the same as described for compound $\mathbf{5 a}$, with the exception that the condensation with $\mathrm{ZGlyOH}$ was allowed to proceed at room temperature for two days; after complete removal of DCU and solvent evaporation, the resulting mixture was eluted on silica with DCM/Acetone 3:1 (v/v); fractions containing pure product were pooled and evaporated to dryness; the resulting white solid (41\%) was recrystallized from ethanol $\left(\mathrm{mp} 195-197^{\circ} \mathrm{C}\right) . \delta_{\mathrm{H}}$ (DMSO$\left.\mathrm{d}_{6}\right), 11.63$ (bs, 1H), 10.36 (s, 1H), 7.94 (d, J=8.7 Hz, 2H), $7.73(\mathrm{~d}, J=8.7 \mathrm{~Hz}, 2 \mathrm{H}), 7.62(\mathrm{t}, J=6.0 \mathrm{~Hz}, 1 \mathrm{H}), 7.38(\mathrm{~m}$, $5 \mathrm{H}), 6.75(\mathrm{~s}, 1 \mathrm{H}), 5.05(\mathrm{~s}, 2 \mathrm{H}), 3.83(\mathrm{~d}, J=6.0 \mathrm{~Hz}, 2 \mathrm{H}), 2.25$ $(\mathrm{s}, 6 \mathrm{H}) ; \delta_{\mathrm{C}}\left(\mathrm{DMSO}-\mathrm{d}_{6}\right), 168.6,168.2,156.5,156.1,142.4$, 136.9, 134.4, 129.3, 128.3, 127.7, 127.6, 117.9, 113.5, 65.4, 44.1, 22.8. Anal. calcd for $\mathrm{C}_{22} \mathrm{H}_{23} \mathrm{~N}_{5} \mathrm{O}_{5} \mathrm{~S}$ (469.5): C, 56.28; H, 4.94; N, 14.92; S, 6.83\%. Found: C, 56.30; H, 4.98; N, $14.80 ; \mathrm{S}, 6.80 \%$.

4.2.3. $N^{4}$-BocAlaSulfamethazine (7a). The synthesis and crude mixture work-up were done as for $\mathbf{5 a}$, with BocAlaOH as the amino acid component; the product was isolated by elution on a silica column with DCM/ Acetonitrile (ACN) 2:1 (v/v); fractions containing only the new product were pooled and solvent evaporated under reduced pressure; the resulting white solid (49\%) was recrystallized from 1:5 (v/v) DCM/ACN (mp 205-206 $\left.{ }^{\circ} \mathrm{C}\right)$. $\delta_{\mathrm{H}}\left(\mathrm{DMSO}-\mathrm{d}_{6}\right), 11.63(\mathrm{bs}, 1 \mathrm{H}), 10.32(\mathrm{~s}, 1 \mathrm{H}), 7.94(\mathrm{~d}$, $J=8.4 \mathrm{~Hz}, 2 \mathrm{H}), 7.75(\mathrm{~d}, J=8.4 \mathrm{~Hz}, 2 \mathrm{H}), 7.18(\mathrm{~d}, J=6.3 \mathrm{~Hz}$, $1 \mathrm{H}), 6.75(\mathrm{~s}, 1 \mathrm{H}), 4.11(\mathrm{~m}, 1 \mathrm{H}), 2.25(\mathrm{~s}, 6 \mathrm{H}), 1.37(\mathrm{~s}, 9 \mathrm{H})$, $1.25(\mathrm{~d}, J=6.0 \mathrm{~Hz}, 3 \mathrm{H}) ; \delta_{\mathrm{C}}\left(\mathrm{DMSO}_{\mathrm{d}}\right), 172.6,168.3,156.2$, 155.2, 142.7, 134.1, 129.3, 118.1, 113.3, 78.1, 50.6, 28.2, 23.0, 17.7. Anal. calcd for $\mathrm{C}_{20} \mathrm{H}_{27} \mathrm{~N}_{5} \mathrm{O}_{5} \mathrm{~S} \cdot 1 / 2 \mathrm{H}_{2} \mathrm{O}$ (458.5): $\mathrm{C}$, 52.39; H, 6.15; N, 15.27; S, 6.99\%. Found: C, 52.57; H, $6.08 ; \mathrm{N}, 15.22 ; \mathrm{S}, 6.70 \%$

4.2.4. $N^{4}$-BocPheSulfamethazine (8a). The condensation of sulfamethazine with BocPheOH was done as described for 5a; the crude mixture was then eluted on silica with $\mathrm{DCM} / \mathrm{ACN}$ 4:1 (v/v), and the product isolated as a white solid (56\%), which was recrystallized from ACN (mp 198$\left.200^{\circ} \mathrm{C}\right) . \delta_{\mathrm{H}}\left(\mathrm{DMSO}_{\mathrm{d}}\right), 11.61(\mathrm{bs}, 1 \mathrm{H}), 10.42(\mathrm{~s}, 1 \mathrm{H}), 7.95$ $(\mathrm{d}, J=8.4 \mathrm{~Hz}, 2 \mathrm{H}), 7.74(\mathrm{~d}, J=8.4 \mathrm{~Hz}, 2 \mathrm{H}), 7.26(\mathrm{~m}, 6 \mathrm{H})$, 6.77 (s, 1H), 4.30 (m, 1H), $2.97(\mathrm{dd}, J=3.4,15.2 \mathrm{~Hz}, 1 \mathrm{H})$, $2.83(\mathrm{dd}, J=3.3,15.3 \mathrm{~Hz}, 1 \mathrm{H}), 2.26(\mathrm{~s}, 6 \mathrm{H}), 1.32(\mathrm{~s}, 9 \mathrm{H}) ; \delta_{\mathrm{C}}$ (DMSO-d $)$ ) 171.6, 167.7, 156.2, 155.4, 142.5, 137.8, 134.6, 129.4, 129.3, 128.1, 126.4, 118.3, 113.9, 78.2, 56.8, 37.2, 28.2, 23.0. Anal. calcd for $\mathrm{C}_{26} \mathrm{H}_{31} \mathrm{~N}_{5} \mathrm{O}_{5} \mathrm{~S} \cdot 1 / 2 \mathrm{H}_{2} \mathrm{O}$ (534.6): $\mathrm{C}$, 58.41; H, 6.03; N, 13.10; S, 6.00\%. Found: C, 58.50; H, $5.80 ; \mathrm{N}, 12.90 ; \mathrm{S}, 6.04 \%$.

4.2.5. $N^{4}$-BocGlyGlySulfamethazine (9a). The synthesis reaction and work-up were performed as described for $\mathbf{5 a}$, using BocGlyGlyOH as the acylating agent; the product was isolated after elution on silica with DCM/Acetone 1:1 (v/v), as a white solid (20\%), which was recrystallized from ethanol $\left(\mathrm{mp} 220-221^{\circ} \mathrm{C}\right) . \delta_{\mathrm{H}}\left(\mathrm{DMSO}_{\mathrm{d}}\right), 11.63(\mathrm{bs}, 1 \mathrm{H})$, $10.22(\mathrm{~s}, 1 \mathrm{H}), 8.22(\mathrm{t}, J=5.4 \mathrm{~Hz}, 1 \mathrm{H}), 7.95(\mathrm{~d}, J=8.4 \mathrm{~Hz}$, 
2H), $7.75(\mathrm{~d}, J=8.4 \mathrm{~Hz}, 2 \mathrm{H}), 7.11(\mathrm{~d}, J=5.7 \mathrm{~Hz}, 1 \mathrm{H}), 6.75$ (s, 1H), $3.92(\mathrm{~d}, J=5.4 \mathrm{~Hz}, 2 \mathrm{H}), 3.61(\mathrm{~d}, J=5.7 \mathrm{~Hz}, 2 \mathrm{H})$, $2.24(\mathrm{~s}, 6 \mathrm{H}), 1.38(\mathrm{~s}, 9 \mathrm{H}) ; \delta_{\mathrm{C}}\left(\mathrm{DMSO}_{\mathrm{d}}\right), 170.0,168.4$, 167.9, 156.2, 156.0, 142.4, 134.6, 129.4, 118.1, 113.5, 78.2, 43.3, 42.8, 28.2, 22.9. Anal. calcd for $\mathrm{C}_{21} \mathrm{H}_{28} \mathrm{~N}_{6} \mathrm{O}_{6} \mathrm{~S} \cdot 1 / 2 \mathrm{H}_{2} \mathrm{O}$ (501.6): C, 50.29; H, 5.83; N, 16.76; S, 6.39\%. Found: C, $50.40 ; \mathrm{H}, 5.60 ; \mathrm{N}, 16.50 ; \mathrm{S}, 6.50 \%$.

4.2.6. $N^{4}$-BocAlaGlySulfamethazine (10a). Both the synthesis and DCU precipitation were as described for $\mathbf{5 a}$, with BocAlaGlyOH as the acyl component; the reaction mixture was eluted on silica with DCM/Acetone $2: 1(\mathrm{v} / \mathrm{v})$, and the product was isolated as a white solid (26\%), which was recrystallized from ACN $\left(\mathrm{mp} 204-206^{\circ} \mathrm{C}\right) . \delta_{\mathrm{H}}$ (DMSO$\left.\mathrm{d}_{6}\right), 11.55(\mathrm{bs}, 1 \mathrm{H}), 10.11(\mathrm{~s}, 1 \mathrm{H}), 8.25(\mathrm{~m}, 1 \mathrm{H}), 7.93(\mathrm{~d}, J=$ $8.1 \mathrm{~Hz}, 2 \mathrm{H}), 7.75(\mathrm{~d}, J=8.1 \mathrm{~Hz}, 2 \mathrm{H}), 7.12(\mathrm{~d}, J=6.3 \mathrm{~Hz}$, $1 \mathrm{H}), 6.76(\mathrm{~s}, 1 \mathrm{H}), 3.98(\mathrm{~m}, 1 \mathrm{H}), 3.88(\mathrm{~d}, J=5.4 \mathrm{~Hz}, 2 \mathrm{H})$, $2.24(\mathrm{~s}, 6 \mathrm{H}), 1.37(\mathrm{~s}, 9 \mathrm{H}), 1.20(\mathrm{~d}, J=7.2 \mathrm{~Hz}, 3 \mathrm{H}) ; \delta_{\mathrm{C}}$ (DMSO-d 6 ), 173.4, 168.4, 167.5, 156.2, 155.4, 142.3, 134.7, 129.4, 118.1, 113.5, 78.3, 49.9, 42.9, 28.2, 22.9, 18.0. Anal. calcd for $\mathrm{C}_{22} \mathrm{H}_{30} \mathrm{~N}_{6} \mathrm{O}_{6} \mathrm{~S}$ (506.6): C, 52.16; H, 5.97; N, 16.59; S, 6.33\%. Found: C, 52.28; H, 6.02; N, 16.60; S, 6.03\%.

4.2.7. $N^{4}$-BocPheGlySulfamethazine (11a). The synthesis reaction and DCU filtration were performed as previously explained for 5a, using BocPheGlyOH as acylating agent; the crude mixture was then eluted on silica with DCM/ACN $2: 1(\mathrm{v} / \mathrm{v})$, and the product was isolated as a white solid $(27 \%)$, which was recrystallized from ACN (mp 194$\left.195^{\circ} \mathrm{C}\right) . \delta_{\mathrm{H}}\left(\mathrm{DMSO}-\mathrm{d}_{6}\right), 11.62(\mathrm{bs}, 1 \mathrm{H}), 10.23(\mathrm{~s}, 1 \mathrm{H}), 8.40$ (m, 1H), $7.94(\mathrm{~d}, J=8.2 \mathrm{~Hz}, 2 \mathrm{H}), 7.75(\mathrm{~d}, J=8.2 \mathrm{~Hz}, 2 \mathrm{H})$, $7.28(\mathrm{~m}, 5 \mathrm{H}), 7.05(\mathrm{~d}, J=8.1 \mathrm{~Hz}, 1 \mathrm{H}), 6.76(\mathrm{~s}, 1 \mathrm{H}), 4.20(\mathrm{~m}$, 1H), $3.94(\mathrm{~m}, 2 \mathrm{H}), 3.03(\mathrm{dd}, J=4.9 \mathrm{~Hz}, 13.9 \mathrm{~Hz}, 1 \mathrm{H}), 2.74$ $(\mathrm{dd}, J=6.0 \mathrm{~Hz}, 13.8 \mathrm{~Hz}, 1 \mathrm{H}), 2.25(\mathrm{~s}, 6 \mathrm{H}), 1.28(\mathrm{~s}, 9 \mathrm{H}) ; \delta_{\mathrm{C}}$ (DMSO- $\mathrm{d}_{6}$ ), 172.4, 168.4, 167.3, 156.2, 155.5, 142.4, 138.3, 134.7, 129.4, 129.2, 128.1, 126.2, 118.1, 113.6, 78.2, 55.8, 42.9, 37.4, 28.1, 22.9. Anal. calcd for $\mathrm{C}_{28} \mathrm{H}_{34} \mathrm{~N}_{6} \mathrm{O}_{6} \mathrm{~S}$ (582.7): C, 57.72; H, 5.88; N, 14.42; S, 5.50\%. Found: C, 57.80; H, $5.94 ; \mathrm{N}, 14.30 ; \mathrm{S}, 5.24 \%$.

4.2.8. $\quad N^{4}$-BocGlySulfadimethoxine $(5 \mathrm{~b})$. To a stirred solution of BocGlyOH (2.0 mmol) in dry THF was carefully added DCCI $(2.2 \mathrm{mmol})$ at $0^{\circ} \mathrm{C}$, followed by sulfadimethoxine $(2.0 \mathrm{mmol})$; the mixture was stirred at $0^{\circ} \mathrm{C}$ for one hour and then at room temperature for two days; DCU was removed by suction filtration and, after THF evaporation, warm acetone was added to the residue; the solution was allowed to stand at $4^{\circ} \mathrm{C}$ overnight and precipitated DCU was removed by filtration; the filtrate was evaporated to dryness and the yellowish solid obtained was then eluted on a silica-gel column, using DCM/Acetone 5:1 (v/v); fractions containing pure product were pooled and evaporated to dryness, giving a yellowish solid (41\%) with $\mathrm{mp}$ 193$195^{\circ} \mathrm{C} . \delta_{\mathrm{H}}\left(\mathrm{CDCl}_{3}\right), 9.28(\mathrm{~s}, 1 \mathrm{H}), 7.73(\mathrm{~d}, J=8.1 \mathrm{~Hz}, 2 \mathrm{H})$, $7.54(\mathrm{~d}, J=8.1 \mathrm{~Hz}, 2 \mathrm{H}), 6.23(\mathrm{~s}, 1 \mathrm{H}), 5.79(\mathrm{~m}, 1 \mathrm{H}), 4.02(\mathrm{~d}$, $J=5.8 \mathrm{~Hz}, 2 \mathrm{H}), 3.89$ (s, 3H), $3.86(\mathrm{~s}, 3 \mathrm{H}), 1.45(\mathrm{~s}, 9 \mathrm{H}) ; \delta_{\mathrm{C}}$ $\left(\mathrm{CDCl}_{3}\right), 172.6,169.0,164.1,159.2,156.8,142.3,134.0$, 128.4, 119.4, 85.7, 80.8, 54.8, 54.2, 45.2, 28.2. $\mathrm{m} / \mathrm{z}$ (467.50): $468.38\left(\mathrm{MH}^{+}\right)$.

4.2.9. $N^{4}$-BocGlyGlySulfadimethoxine (6b). The procedure to react sulfadimethoxine with BocGlyGlyOH was as described for $\mathbf{5 b}$, but in this case reaction was allowed to proceed for four days and DCU was precipitated from THF instead of acetone; the crude mixture was eluted on a silicagel column, using DCM/THF 4:1 (v/v); fractions containing pure product were pooled and evaporated to dryness, giving a white solid $(55 \%)$ with $\mathrm{mp} 223-224^{\circ} \mathrm{C} . \delta_{\mathrm{H}}\left(\mathrm{DMSO}-\mathrm{d}_{6}\right)$, $10.29(\mathrm{~s}, 1 \mathrm{H}), 8.19(\mathrm{t}, J=5.4 \mathrm{~Hz}, 1 \mathrm{H}), 7.87(\mathrm{~d}, J=8.9 \mathrm{~Hz}$, 2H), $7.76(\mathrm{~d}, J=8.9 \mathrm{~Hz}, 2 \mathrm{H}), 7.07$ (t, $J=5.9 \mathrm{~Hz}, 1 \mathrm{H}), 5.91$ (s, $1 \mathrm{H}), 3.90$ (d, J=5.5 Hz, 2H), 3.77 (s, 3H), 3.73 (s, 3H), 3.58 $(\mathrm{d}, J=6.2 \mathrm{~Hz}, 2 \mathrm{H}), 1.35(\mathrm{~s}, 9 \mathrm{H}) ; \delta_{\mathrm{C}}\left(\mathrm{DMSO}_{\mathrm{d}}\right), 171.7$, $170.1,168.5,164.3,160.0,156.0,143.0,133.8,128.6$, $118.8,84.6,78.3,54.6,53.9,43.3,42.8,28.2 . \mathrm{m} / \mathrm{z}(524.55)$ : $525.43\left(\mathrm{MH}^{+}\right)$.

4.2.10. $N^{4}$-BocAlaGlySulfadimethoxine (7b). The synthesis was performed as described for $\mathbf{6 b}$, using BocAla GlyOH as acyl component; the crude mixture was eluted on a silica-gel column, using DCM/THF 4:1 (v/v); fractions containing pure product were pooled and evaporated to dryness, resulting a yellowish solid (56\%)

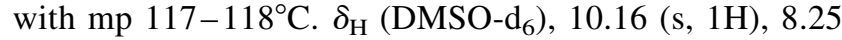
$(\mathrm{m}, 1 \mathrm{H}), 7.87(\mathrm{~d}, J=8.5 \mathrm{~Hz}, 2 \mathrm{H}), 7.76(\mathrm{~d}, J=8.5 \mathrm{~Hz}, 2 \mathrm{H})$, 7.09 (d, $J=6.8 \mathrm{~Hz}, 1 \mathrm{H}), 5.91(\mathrm{~s}, 1 \mathrm{H}), 3.96(\mathrm{q}, J=7.1 \mathrm{~Hz}$, $1 \mathrm{H}), 3.88(\mathrm{~d}, J=5.3 \mathrm{~Hz}, 2 \mathrm{H}), 3.76(\mathrm{~s}, 3 \mathrm{H}), 3.72(\mathrm{~s}, 3 \mathrm{H})$, $1.33(\mathrm{~s}, 9 \mathrm{H}), 1.18(\mathrm{~d}, J=7.1 \mathrm{~Hz}, 3 \mathrm{H}) ; \delta_{\mathrm{C}}\left(\mathrm{DMSO}_{6}\right)$, $173.6,171.6,166.6,164.4,160.0,155.6,143.0,133.9$, $128.7,118.9,84.7,78.5,54.7,54.0,50.0,43.0,28.3,16.0$. $\mathrm{m} / z$ (538.58): $538.99\left(\mathrm{MH}^{+}\right)$.

4.2.11. $N^{4}$-BocPheGlySulfadimethoxine $(8 \mathrm{~b})$. The synthesis was performed as described for $\mathbf{6 b}$, using BocPhe GlyOH as acylating agent; the crude mixture was eluted on a silica-gel column, using DCM/Acetone 8:1 (v/v); fractions containing pure product were pooled and evaporated to dryness, resulting a yellowish solid (52\%) with $\mathrm{mp}$ 186$187^{\circ} \mathrm{C} . \delta_{\mathrm{H}}\left(\mathrm{DMSO}_{-} \mathrm{d}_{6}\right), 10.28(\mathrm{~s}, 1 \mathrm{H}), 8.38(\mathrm{t}, J=5.5 \mathrm{~Hz}$, $1 \mathrm{H}), 7.88(\mathrm{~d}, J=9.0 \mathrm{~Hz}, 2 \mathrm{H}), 7.77(\mathrm{~d}, J=9.0 \mathrm{~Hz}, 2 \mathrm{H}), 7.20$ (m, 5H), $7.03(\mathrm{~d}, J=8.3 \mathrm{~Hz}, 1 \mathrm{H}), 5.92(\mathrm{~s}, 1 \mathrm{H}), 4.20(\mathrm{~m}, 1 \mathrm{H})$, $3.92(\mathrm{~d}, J=5.4 \mathrm{~Hz}, 2 \mathrm{H}), 3.77$ (s, 3H), 3.73 (s, 3H), 2.98 (dd, $J=4.0 \mathrm{~Hz}, 13.8 \mathrm{~Hz}, 1 \mathrm{H}), 2.77$ (dd, $J=10.5 \mathrm{~Hz}, 13.5 \mathrm{~Hz}$, $1 \mathrm{H}), 1.34(\mathrm{~s}, 9 \mathrm{H}) ; \delta_{\mathrm{C}}\left(\mathrm{DMSO}_{6}\right), 172.4,171.7,166.4$, $164.3,160.1,155.5,142.9,138.2,133.8,129.2,128.6$, $128.1,126.2,118.8,84.6,78.2,55.8,54.6,53.8,42.9,37.4$, 28.3. $\mathrm{m} / \mathrm{z}$ (614.68): $615.49\left(\mathrm{MH}^{+}\right)$.

4.2.12. $N^{4}$-BocGlySulfamethoxypyridazine $(5 \mathrm{c})$. Tо a stirred solution of BocGlyOH $(2.0 \mathrm{mmol})$ in dry THF was carefully added DCCI $(2.2 \mathrm{mmol})$ at $0^{\circ} \mathrm{C}$, followed by sulfamethoxypyridazine $(2.0 \mathrm{mmol})$; the mixture was stirred at $0^{\circ} \mathrm{C}$ for $1 \mathrm{~h}$ and then at room temperature for two days; DCU was removed by suction filtration and, after THF evaporation, warm acetone was added to the residue; the solution was allowed to stand at $4^{\circ} \mathrm{C}$ overnight and precipitated DCU was removed by filtration; the filtrate was evaporated to dryness and the yellowish solid obtained was then eluted on a silica-gel column, using DCM/Acetone $5: 1(\mathrm{v} / \mathrm{v})$; fractions containing pure product were pooled and evaporated to dryness, giving a yellowish solid (43\%) with mp $105-107^{\circ} \mathrm{C} . \delta_{\mathrm{H}}\left(\mathrm{DMSO}-\mathrm{d}_{6}\right), 10.29(\mathrm{~s}, 1 \mathrm{H}), 7.77(\mathrm{~d}, J=$ $8.9 \mathrm{~Hz}, 2 \mathrm{H}), 7.70(\mathrm{~d}, J=9.8 \mathrm{~Hz}, 1 \mathrm{H}), 7.69(\mathrm{~d}, J=8.9 \mathrm{~Hz}$, $2 \mathrm{H}), 7.34(\mathrm{~d}, J=9.8 \mathrm{~Hz}, 1 \mathrm{H}), 7.10(\mathrm{t}, J=6.0 \mathrm{~Hz}, 1 \mathrm{H}), 3.80(\mathrm{~s}$, $3 \mathrm{H}), 3.70(\mathrm{~d}, J=6.0 \mathrm{~Hz}, 2 \mathrm{H}), 1.36(\mathrm{~s}, 9 \mathrm{H}) ; \delta_{\mathrm{C}}\left(\mathrm{DMSO}_{\mathrm{d}}\right)$, 168.9, 156.0, 153.0, 142.1, 127.4, 118.7, 78.2, 54.6, 43.9, 28.2. $\mathrm{m} / \mathrm{z}$ (437.47): $438.13\left(\mathrm{MH}^{+}\right)$. 
4.2.13. $N^{4}$-BocGlyGlySulfamethoxypyridazine (6c). The procedure to react sulfamethoxypyridazine with BocGly $\mathrm{GlyOH}$ was as described for 5c; the crude mixture was eluted on a silica-gel column, using DCM/THF 1:1 (v/v); fractions containing pure product were pooled and evaporated to dryness, giving a white solid (37\%) with mp 189$191^{\circ} \mathrm{C} . \delta_{\mathrm{H}}\left(\mathrm{DMSO}-\mathrm{d}_{6}\right), 10.20(\mathrm{~s}, 1 \mathrm{H}), 8.19(\mathrm{~m}, 1 \mathrm{H}), 7.78(\mathrm{~d}$, $J=8.7 \mathrm{~Hz}, 2 \mathrm{H}), 7.70(\mathrm{~d}, J=9.8 \mathrm{~Hz}, 1 \mathrm{H}), 7.69(\mathrm{~d}, J=8.7 \mathrm{~Hz}$, $2 \mathrm{H}), 7.34(\mathrm{~d}, J=9.8 \mathrm{~Hz}, 1 \mathrm{H}), 7.07(\mathrm{~m}, 1 \mathrm{H}), 3.90(\mathrm{~d}, J=$ $5.1 \mathrm{~Hz}, 2 \mathrm{H}), 3.60(\mathrm{~s}, 3 \mathrm{H}), 3.59(\mathrm{~d}, J=5.7 \mathrm{~Hz}, 2 \mathrm{H}), 1.35(\mathrm{~s}$, $9 \mathrm{H}) ; \delta_{\mathrm{C}}\left(\mathrm{DMSO}-\mathrm{d}_{6}\right), 170.0,168.3,156.0,142.0,127.4$, $126.3,125.1,118.8,78.2,54.5,43.3,42.8,28.2 . \mathrm{m} / \mathrm{z}$ (494.52): $495.14\left(\mathrm{MH}^{+}\right)$.

4.2.14. $N^{4}$-BocAlaGlySulfamethoxypyridazine (7c). The synthesis was performed as described for $\mathbf{5 c}$, using BocAlaGlyOH as the acyl component. The crude mixture was eluted on a silica-gel column, using DCM/Acetone 4:1 $(\mathrm{v} / \mathrm{v})$; fractions containing pure product were pooled and evaporated to dryness, yielding a yellowish solid (60\%) with $\mathrm{mp} 122-125^{\circ} \mathrm{C} . \delta_{\mathrm{H}}\left(\mathrm{DMSO}-\mathrm{d}_{6}\right), 10.10(\mathrm{~s}, 1 \mathrm{H}), 8.23(\mathrm{t}, J=$ $5.5 \mathrm{~Hz}, 1 \mathrm{H}), 7.78(\mathrm{~d}, J=9.1 \mathrm{~Hz}, 2 \mathrm{H}), 7.72(\mathrm{~d}, J=9.1 \mathrm{~Hz}$, 2H), $7.71(\mathrm{~d}, J=9.8 \mathrm{~Hz}, 1 \mathrm{H}), 7.34(\mathrm{~d}, J=9.8 \mathrm{~Hz}, 1 \mathrm{H}), 7.09$ $(\mathrm{d}, J=6.8 \mathrm{~Hz}, 1 \mathrm{H}), 3.96(\mathrm{q}, J=7.0 \mathrm{~Hz}, 3 \mathrm{H}), 3.88(\mathrm{~d}, J=$ $5.4 \mathrm{~Hz}, 2 \mathrm{H}), 3.81(\mathrm{~s}, 3 \mathrm{H}), 1.35(\mathrm{~s}, 9 \mathrm{H}) ; \delta_{\mathrm{C}}\left(\right.$ DMSO- $\left._{6}\right)$, 173.4, 168.3, 155.4, 152.9, 141.9, 127.4, 126.2, 118.8, 78.3, 54.5, 49.9, 42.8, 28.2, 17.9. $\mathrm{m} / \mathrm{z}(508.55): 508.98\left(\mathrm{MH}^{+}\right)$.

4.2.15. $N^{4}$-BocPheGlySulfamethoxypyridazine (8c). The synthesis was performed as described for $\mathbf{5 c}$, using BocPheGlyOH as acylating agent; the crude mixture was eluted on a silica-gel column, using DCM/Acetone 4:1 $(\mathrm{v} / \mathrm{v})$; fractions containing pure product were pooled and evaporated to dryness, yielding a yellowish solid (52\%) with mp $125-128^{\circ} \mathrm{C} . \delta_{\mathrm{H}}\left(\right.$ DMSO-d $\left._{6}\right), 10.21(\mathrm{~s}, 1 \mathrm{H}), 8.37(\mathrm{t}$, $J=5.5 \mathrm{~Hz}, 1 \mathrm{H}), 7.78(\mathrm{~d}, J=9.0 \mathrm{~Hz}, 2 \mathrm{H}), 7.72(\mathrm{~d}, J=9.0 \mathrm{~Hz}$, 2H), $7.71(\mathrm{~d}, J=9.9 \mathrm{~Hz}, 1 \mathrm{H}), 7.34(\mathrm{~d}, J=9.9 \mathrm{~Hz}, 1 \mathrm{H}), 7.20$ $(\mathrm{m}, 5 \mathrm{H}), 7.02(\mathrm{~d}, J=8.3 \mathrm{~Hz}, 1 \mathrm{H}), 4.20(\mathrm{~m}, 1 \mathrm{H}), 3.92(\mathrm{~d}$, $J=5.1 \mathrm{~Hz}, 2 \mathrm{H}), 3.81(\mathrm{~s}, 3 \mathrm{H}), 3.05(\mathrm{dd}, J=3.8,13.7 \mathrm{~Hz}, 3 \mathrm{H})$, $2.74(\mathrm{dd}, J=11.0,14.0 \mathrm{~Hz}, 1 \mathrm{H}), 1.26(\mathrm{~s}, 9 \mathrm{H}) ; \delta_{\mathrm{C}}$ (DMSO$\left.\mathrm{d}_{6}\right), 172.4,168.3,155.5,153.0,142.0,138.2,129.3,128.1$, $127.5,126.3,118.8,78.3,55.9,54.6,42.9,37.4,28.2 . \mathrm{m} / \mathrm{z}$ (584.65): $585.72\left(\mathrm{MH}^{+}\right)$.

4.2.16. $N^{1}$-ZGlySulfisoxazole $(5 \mathrm{~d})$. The synthesis procedure was exactly the same as described for compound $\mathbf{6 a}$, replacing sulfamethazine by sulfisoxazole; the crude mixture was eluted on silica with DCM/Acetone 10:1 $(\mathrm{v} / \mathrm{v})$; fractions containing the major product (somewhat contaminated) were pooled and evaporated to dryness; the resulting yellowish solid (8\%) was identified as $N^{1}$ ZGlySulfisoxazole by NMR spectroscopy. $\delta_{\mathrm{H}}\left(\right.$ DMSO- $\left._{6}\right)$, $7.62(\mathrm{~d}, J=8.7 \mathrm{~Hz}, 2 \mathrm{H}), 7.55(\mathrm{t}, J=6.0 \mathrm{~Hz}, 1 \mathrm{H}), 7.34(\mathrm{~m}, 5 \mathrm{H})$, $6.68(\mathrm{~d}, J=8.7 \mathrm{~Hz}, 2 \mathrm{H}), 6.54(\mathrm{~s}, 2 \mathrm{H}), 5.01(\mathrm{~s}, 2 \mathrm{H}), 3.52(\mathrm{~d}, J=$ $6.0 \mathrm{~Hz}, 2 \mathrm{H}), 2.26$ (s, 3H), $1.90(\mathrm{~s}, 3 \mathrm{H}) ; \delta_{\mathrm{C}}\left(\right.$ DMSO-d $\left._{6}\right), 168.8$, 160.2, 156.8, 156.2, 153.7, 136.9, 128.8, 124.4, 128.3, 127.7, 127.6, 112.8, 104.6, 65.3, 44.2, 10.3, 5.8. Anal. calcd for $\mathrm{C}_{21} \mathrm{H}_{22} \mathrm{~N}_{4} \mathrm{O}_{6} \mathrm{~S}(458.5): \mathrm{C}, 55.01 ; \mathrm{H}, 4.84 ; \mathrm{N}, 12.22 ; \mathrm{S}, 6.99 \%$. Found: C, 54.77; H, 4.78; N, 11.70; S, 6.80\%.

\subsection{Computational details}

Semi-empirical and density functional calculations have been carried out by employing the GAMESS-US suite of programs..$^{35}$ The semi-empirical calculations at the PM3 level of theory were performed to study extensively all relevant conformations of both sulfonamide and corresponding products of acylation by amino acids. Density functional theory (DFT) calculations within the KohnSham formalism were carried out using the B3LYP threeparameter hybrid method proposed by Becke. ${ }^{36}$ This approach comprises an exchange-correlation functional that mixes the non-local Fock exchange with the gradientcorrected form of $\mathrm{Becke}^{37}$ and adds the correlation functional proposed by Lee et al. ${ }^{38}$

Different basis sets were used to describe the atomic electron density and all-electrons have been explicitly included in the calculations. For the most stable conformations, B3LYP full-optimization of geometry and analytical calculation of vibrational frequencies were carried out employing the 6-31G* basis set, ${ }^{39}$ with one d polarization function. Single-point runs were also performed at the optimized geometries using the B3LYP/6-311+G** approach. ${ }^{39}$ The present approach is known to generate very good optimized structures and also accurate thermochemical data. ${ }^{40}$ These calculations have been performed using the GAMESS-US package.

Frequencies were computed for all optimized species in order to characterize each stationary point as a minimum and to correct computed electronic energy values for ZeroPoint Energies, ZPE, as well as translational, rotational and vibrational contributions to the enthalpy at $T=298.15 \mathrm{~K}$. As suggested by Scott et al., ${ }^{41}$ ZPE values were scaled by a factor of 0.9804 which was introduced in the calculation of frequencies.

\section{Acknowledgements}

The authors are indebted to Carlos Lopes, Elvira Garcia and Susana Peixoto for laboratorial assistance, and also to Drs. Eliandre de Oliveira (University of Barcelona) for MS analyses, Isabel Rocha (University of Porto) for elemental analyses, and Adelina Macedo (University of Porto) for NMR spectra. The authors equally thank Fundação para a Ciência e Tecnologia (FCT, Lisbon-Portugal) for financial support through both the research project POCTI/ FCB/39218/2001 (PG and RM) and the post-doctoral research grant SFRH/BPD/11582/2002 (JRBG). P. G. is deeply grateful to Professors M. J. Amaral-Trigo and M. I. Oliveira Santos for helpful discussions and support.

\section{References}

1. Friis, G. J.; Bundgaard, H. In A Textbook of Drug Design and Development; 2nd ed. Krogsgaard-Larsen, P. T. L, Madsen, U., Eds.; Harwood: Amsterdam, 1996.

2. Bundgaard, H. In Biorreversible Carriers in Drug Design. Theory and Application; Roche, E., Ed.; Pergamon: New York, 1987.

3. Sim, S. K. Amer. J. Pharm. 1971, 143, 165. 
4. Defenoyl, O.; Alvarez, M.; Richet, H.; Febvre, M.; Rochemaure, J. Ann. Med. Intern. 1986, 137, 360-360.

5. Bray, P. G.; Ward, S. A. FEMS Microbiol. Lett. 1993, 113, $1-7$.

6. Mandell, G. L.; Sande, M. A. In The Pharmacological Basis of Therapeutics; Gilman, A. G., Rall, T. W., Nies, A. S., Taylor, P., Eds.; Pergamon: New York, 1987.

7. Takahashi, T.; Hosoya, N.; Endo, T.; Nakamura, T.; Sakashita, H.; Kimura, K.; Ohnishi, K.; Nakamura, Y.; Iwamoto, A. J. Clin. Microbiol. 2000, 38, 3161-3164.

8. Silverman, R. B. The Organic Chemistry of Drug Design and Drug Action; Academic: London, 1992.

9. Albala, D. M.; Prien, E. L.; Galal, H. A. J. Endourol. 1994, 8, 401-403.

10. Martindale: The Extra Pharmacopoeia; 31 st ed. Reynolds, J. E. F., Ed.; The Royal Pharmaceutical Society: London, 1996.

11. Plosker, G. L.; Tavish, D. Drugs 1994, 47, 622-651.

12. Kaur, I. P.; Singh, M.; Kanwar, M. Int. J. Pharm. 2000, 199, 119-127.

13. Famaey, J. P. Inflamm. Res. 1997, 46, 437-446.

14. Bundgaard, H.; Johansen, M. J. Pharm. Sci. 1980, 69, 44-46.

15. Larsen, J. D.; Bundgaard, H. Int. J. Pharm. 1987, 37, 87-95.

16. Bundgaard, H.; Larsen, J. D. J. Med. Chem. 1988, 31, 2066-2069.

17. Lopes, F.; Moreira, R.; Iley, J. Bioorg. Med. Chem. 2000, 8, $707-716$

18. Vigroux, A.; Bergon, M.; Zedde, C. J. Med. Chem. 1995, 38, 3983-3994.

19. Capasso, S.; Vergara, A.; Mazzarella, L. J. Am. Chem. Soc. 1998, 120, 1990-1995.

20. Lloyd-Williams, P.; Albericio, F.; Giralt, E. Chemical Approaches to the Synthesis of Peptides and Proteins; CRC: Boca Raton, 1997.

21. Sheehan, J. C.; Hess, G. P. J. Am. Chem. Soc. 1959, 77, $1067-1068$.
22. Knorr, R.; Trzeciak, A.; Bannwarth, W.; Gillessen, D. Tetrahedron Lett. 1989, 30, 1927-1930.

23. Dourtglou, V.; Gross, B.; Lambropoulou, V.; Zioudrou, C. Synthesis 1994, 572-574.

24. Wieland, T.; Seeliger, A. Chem. Ber. 1971, 104, 3992-3994.

25. Koenig, W.; Geiger, R. Chem. Ber. 1970, 103, 2024-2034.

26. Jou, G.; González, I.; Albericio, F.; Lloyd-Williams, P.; Giralt, E. J. Org. Chem. 1997, 62, 354-366.

27. Steglich, W.; Höfle, G. Angew. Chem., Int. Ed. Engl. 1969, 8, 981-985.

28. Bharatam, P. V.; Amita, A. G.; Kaur, D. Tetrahedron 2002, 58, $1759-1764$.

29. Reed, A. E.; Curtiss, L. A.; Weinhold, F. Chem. Rev. 1988, 88, 899-926.

30. Ziegler, J. B.; Shabica, A. C. J. Am. Chem. Soc. 1951, 76, 594-595.

31. Parks, O. W. J. Assoc. Off. Anal. Chem. 1994, 77, 486-489.

32. Chem. Abstr. 1956, 50, 16750g.

33. Chem. Abstr. 1956, 50, 10133h.

34. Rose, F. L.; Swain, G. J. Chem. Soc. 1945, part II, 689-692.

35. GAMESS-US Version 26/10/2000 Schmidt, M. W. Baldridge, K. K.; Boatz, J. A.; Elbert, S. T.; Gordon, M. S.; Jensen, J. H.; Koseki, S.; Matsunaga, N.; Anguyen, K. A.; Su, S. J.; Windus, T. L.; Dupuis, M.; Montgomery, J. A. J. Comput. Chem. 1993, 14, 1347-1363.

36. Becke, A. D. J. Chem. Phys. 1993, 98, 5648-5652.

37. Becke, A. D. Phys. Rev. A 1988, 38, 3098-3100.

38. Lee, C.; Yang, W.; Parr, R. G. Phys. Rev. B 1980, 37, 785-789.

39. Basis set was obtained from the Extensible Computational Chemistry Environment Basis Set Database, http://www.emsl. pnl.gov:2080/forms/basisform.html, Version 2/12/03.

40. Gomes, J. R. B.; Ribeiro da Silva, M. A. V. J. Phys. Chem. A 2003, 107, 869-874.

41. Scott, A. P.; Radom, L. J. Phys. Chem. 1996, 100, $16502-16513$ 